\title{
sciendo
}

Folia Oeconomica Stetinensia

Volume 20 (2020) Issue 1

DOI: $10.2478 /$ foli-2020-0023
WYDZIAL NAUK EKONOMICZNYCH I ZARZĄDZANIA

\section{METHODS OF A MULTIVARIATE ANALYSIS OF NON-METRIC DATA IN EVALUATING THE GENERATIONAL PERCEPTION OF SOCIAL CHARACTERISTICS*}

\author{
Agnieszka Stanimir, Ph.D., Associate Professor \\ Wroclaw University of Economics \\ Faculty of Economics and Finance \\ Department of Econometrics and Operational Research \\ Komandorska 118/120, 53-345 Wroctaw, Poland \\ e-mail: agnieszka.stanimir@ue.wroc.pl \\ ORCID: 0000-0002-9206-9210
}

Received 12 November 2019, Accepted 30 March 2020

\begin{abstract}
Research background: The search for factors influencing the evaluation of the quality of life in terms of subjective and objective socio-economic aspects was the background of the study. The search for perfect multivariate statistical methods in the describing of the assessments made by respondents in variable groups, as well as the categories was carried out.

Purpose: The aim of the study was to recognize the natural areas of transferring subjective satisfaction with the level of social factors in the three groups describing: household, country of residence, and the EU. The determined natural relations between the factors were then compared with the established sets of those factors. The characteristics of behaviour were compared in three generations of the EU.

Research methodology: The Standard Eurobarometer, autumn 2018, provided data describing adults from the generations $\mathrm{Y}, \mathrm{X}$, and $\mathrm{BB}$. In the analysis a factor analysis and correspondence analysis were used.

Results: The effect of the used methods is a multidirectional image of the evaluations made by the EU Generations Y, X and BB in the areas of an individual's functioning: direct (the household), close (the country of residence), and further (Europe and the EU).
\end{abstract}

\footnotetext{
* The project was financed under the program of the Minister of Science and Higher Education under the name "Regional Initiative of Excellence" in 2019-2022 project number 015/RID/2018/19 the amount of funding PLN 10721040.00.
}

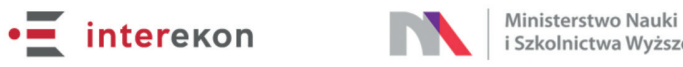


Novelty: The conducted analysis indicates the need to use diverse methods in order that the assumed research objectives are thoroughly realized. The article indicates the possibility of modifying the approach in using the Burt matrix in connection with concatenated contingency tables.

Keywords: generations Y, X, BB; correspondence analysis, factor analysis, quality of life

JEL classification: C3, I31, R2, R5

\section{Introduction}

The aim of the study was to find differences between three generations of adult Europeans from the viewpoint of their evaluations regarding three areas of an individual's functioning: direct (household), close (place and country of residence), further (the EU and Europe). The author aimed at showing whether there are connections between the variables describing particular areas, and what variables influence a higher and a lower evaluation of the determined areas. The indirect objective enabling the realization of the main aim was to indicate methods of a multivariate statistical analysis which will allow for an in-depth examination of the posed problem. The assessments provided by Europeans were of a subjective nature; hence it would be difficult to search for non-model methods to evaluate the set problem.

The research looked for differences between the assessment made by three generations: Baby Boomers (1946-1964), Generation X (1965-1979), and Generation Y (1980-2000). In the literature it is possible to find many studies highlighting the differences between generations in different spheres of their existence: social and consumer behaviour (Haque, Maheshwari, 2015; Belleau, Summers, Xu, Pinel, 2007; Lyons, Duxbury, Higgins, 2007; Madudova, Fabuš, 2017; Lichy, 2012; Ngobo, Devallet-Ezanno, 2010), personal vs. professional(Bąkowska, 2013; Favero, Heath, 2012; Hansen, Leuty, 2012; Mencl, Lester, 2014; Parry, Urwin, 2011; Soulez, GuillotSoulez, 2011; Treuren, Anderson, 2010; Twenge, Campbell, Hoffman, Lance, 2010; Twenge, King, 2005; Vui-Yee, Paggy, 2018), and the use of new technologies (Madudova, Fabuš, 2017). However, according to G. Treuren and K. Anderson (2010), it should be considered whether these generations are decidedly different. Each of them has at its disposal a different set of tools - economic, financial, social, and technical - and represents a different level of knowledge, advancement and need of use. One should point out that younger generations seen from the perspective of the older ones will always be different, because their ways of behaving and 
decision-making are influenced by the changing social, economic, political and technological conditions.

The thus posed research problem is very strongly connected with the quality of life seen in a subjective way. Quality of life is the concept of personal well-being measured by social indicators, in other words the set of non-material characteristics of individuals shaping their opportunities in life, diversified in its cultural and social aspects. For individuals, their subjective well-being is of primary importance, comparing themselves and their opportunities and circumstances with those of others. The measure of subjective well-being includes the perceived quality of life, i.e. the satisfaction drawn by people from different aspects of life as a whole, and also the elements related to the experienced emotional states and their system of values (Jakość..., 2017). Thus, according to M. Olsson and B.J. Schuller (2012, p. 6), "people are concerned about the connection between globalization and national living standard", and therefore their subjective assessments often do not result from their evaluation of the actual living standard but from the comparisons which they conduct looking at living standards in other regions or other countries. In the opinion of P. Nowak (2018), quality of life should be examined both on an individual and social level because it may be considered as a subjective view of a given person as well as an objective one, based on the relevant statistics.

The research was based on the assumption that both the positive and negative evaluation of the quality of life in respect of the characteristics closest to an individual and describing him/ her exactly, is linked with the evaluation of their life and functioning in the environment in the areas characterized by features not directly connected with an individual. Therefore, how the quality of life is evaluated implies the assessment of the possibility of functioning in society, and reaching out further, in the EU and in Europe. The way an individual evaluates solutions which are relevant to him/her, and are proposed in the EU, translates into comparing them with what is offered in his/her own country and the place of residence. Thus one can expect here feedback from particular factors, and on such a basis the following research hypotheses were formed:

H1: Factors describing satisfaction with quality of life and its socio-economic aspects are interwoven and do not constitute separate areas of an individual's functioning such as the household, country and place of residence, as well as the EU and Europe.

H2: The perception of the household's quality of life is interpreted as the perception of the quality of life in the country and place of residence, the EU and Europe.

H3: There are differences between the distinguished generational groups regarding the realization of the problems defined in hypotheses $\mathrm{H} 1$ and $\mathrm{H} 2$. 


\section{Data and applied methods of analysis}

The study used data gathered during the Standard Eurobarometer (European Commission, 2019) survey conducted in November 2018 in all EU member states as well as in countries applying for EU accession. The survey is cyclical, carried out twice a year using a personal interview. The research was based on the answers of adult citizens of the European Union from the generations $\mathrm{Y}, \mathrm{X}$ and $\mathrm{BB}$. The analyses used the following variables: general condition of the country (X1), evaluation of the country's economy (X2), evaluation of the EU economy (X3), personal situation at work (X4), financial condition of the household (X5), evaluation of the country's job market (X6), evaluation of public services (X7), satisfaction with one's life (X8), expectations from one's life (X9), quality of life was better before EU accession (X10), satisfaction with democracy in the country (X11), satisfaction with EU democracy (X12), attachment to the place of residence (X13), attachment to the country (X14), attachment to the EU (X15), attachment to Europe (X16), feelings about the statement my voice counts in the $E U$ (X17) and my voice counts in the country (X18), convincing acquaintances to my opinion (X19). The measure of the variables was carried out using a five-step scale, where the highest score was the most positive opinion (except for question X10). It was assumed that the variables describe the three areas of respondents' functioning: household (X4, X5, X8, X9, X10, X13, $\mathrm{X} 19)$ - HH, country of residence (X1, X2, X6, X7, X11, X14, X18) - C, the European Union (X3, X12, X15, X16, X17) - EU.

In order to verify the hypotheses and realise the postulated research problem, a factor analysis and correspondence analysis were used. These methods have been widely described in the literature. For instance, a factor analysis is presented in publications by K. Backhaus, B. Erichson, W. Plinke and R. Weiber (2003), M. Greenacre (2010), J.-O. Kim and C. Mueller (1978), L. Lebart, A. Morineau and K.M. Warwick (1984), A. Ptak-Chmielewska (2009), A. Sagan (1998), and M. Sztemberg-Lewandowska (2008); correspondence analysis features in many publications by M. Greenacre (e.g. 1984, 2010), A. Stanimir (e.g. 2005), as well as those by K. Backhaus, B. Erichson, W. Plinke and R. Weiber (2003), J. Blasius (2001), L. Lebart, A. Morineau and K.M. Warwick (1984). This article does not present algorithms of conducting an analysis using the selected methods, but merely refers to the indicators and assumptions regarding the correctness of the conclusions made.

The factor analysis is the method enabling to indicate latent structures which occur among the variables describing the analysed phenomenon. In the exploratory approach, the search for latent structures takes place outside the researcher's influence on their construction. A. Sagan 
(1998) pointed out that a factor analysis can be employed when the variables are described by at least five to seven categories with the optimum number of observations amounting to 2,000.

Using a correspondence analysis, it is possible to examine the relations between the categories of non-metric variables. The result of this method is an indication of the groups of coexistent categories and their graphic presentation. Considerations carried out in this research point to the application of a correspondence analysis of multiple variables. The main issue to be dealt with during the analysis is the loss of information about the connections between the categories, which takes place when reducing their full-dimensional space. In such a case one of the following approaches can be used:

a) the Burt matrix - symmetrical block matrix including all the analysed variables, in which on the main diagonal there are diagonal matrices containing numbers of occurrences of the categories of the following variables, and beyond the diagonal there are contingency tables of the pairs of variables;

b) the Burt matrix with supplementary points - for the set of variables, correspondence analysis of the Burt matrix is carried out, while the coordinates for projecting categories of the remaining variables are calculated and based on the solutions obtained for the active categories;

c) classic correspondence analysis of the reconstitution Burt matrix for the selected set of variables with supplementary points determined on the basis of the observation of the other variables;

d) concatenated Burt matrix - constructed and based on the Burt matrices selected from the available set of variables and contingency tables, however concatenated with the Burt matrix in a defined way. The variables and categories constituting the Burt matrix are treated as common factors, adding to the Burt matrix further tables of contingency between new variables and the variables recorded in the Burt matrix. Table 1 shows a graphic representation of that table: variables $X, Y$, and $Z$ constitute the Burt matrix, and together with variable $W$ make up a concatenated contingency table. For the table constructed in such a way the contingency analysis is carried out in accordance with the classic approach. 
Table 1. Example of the construction of a concatenated contingency table of the Burt matrix

\begin{tabular}{|c|c|c|c|c|c|c|c|c|c|c|}
\hline & & & \multirow{2}{*}{\multicolumn{3}{|c|}{$X$}} & \multirow{2}{*}{\multicolumn{3}{|c|}{$\mathrm{Y}$}} & \multirow{2}{*}{\multicolumn{2}{|c|}{$\mathrm{Z}$}} \\
\hline & & & & & & & & & & \\
\hline & & & $\mathrm{X}_{1}$ & $\mathrm{X}_{2}$ & $\mathrm{X}_{3}$ & $\mathrm{Y}_{1}$ & $\mathrm{Y}_{2}$ & $\mathrm{Y}_{3}$ & $Z_{1}$ & $\mathrm{Z}_{2}$ \\
\hline \multirow{8}{*}{ 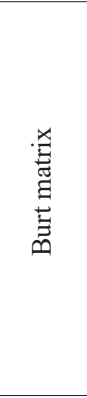 } & \multirow{3}{*}{$X$} & $\mathrm{X}_{1}$ & & & & & & & & \\
\hline & & $\mathrm{X}_{2}$ & & & & & & & & \\
\hline & & $\mathrm{X}_{3}$ & & & & & & & & \\
\hline & \multirow{3}{*}{$\mathrm{Y}$} & $\mathrm{Y}_{1}$ & & & & & & & & \\
\hline & & $\mathrm{Y}_{2}$ & & & & & & & & \\
\hline & & $\mathrm{Y}_{3}$ & & & & & & & & \\
\hline & \multirow{2}{*}{$\mathrm{Z}$} & $Z_{1}$ & & & & & & & & \\
\hline & & $\mathrm{Z}_{2}$ & & & & & & & & \\
\hline \multirow{5}{*}{ 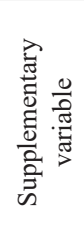 } & \multirow{5}{*}{ W } & $\mathrm{W}_{1}$ & & & & & & & & \\
\hline & & $\mathrm{W}_{2}$ & & & & & & & & \\
\hline & & $\mathrm{W}_{3}$ & & & & & & & & \\
\hline & & $\mathrm{W}_{4}$ & & & & & & & & \\
\hline & & $\mathrm{W}_{5}$ & & & & & & & & \\
\hline
\end{tabular}

Source: own elaboration.

The ways of carrying out a correspondence analysis with modes 3 and 4 were described briefly in (Greenacre, Blasius, 2006) and in detail presented by Michael Greenacre at the IFCS conference in Thessaloniki in August 2019.

\section{Search for natural latent factors}

The factor analysis was conducted separately for each of the generations in question with the use of the method of the main components to distinguish the common factors and the Varimax rotation. In each of the cases, the interpretation of a scree test led to determining three latent factors. In order to distinguish the latent factors a condition regarding the level of eigenvalue was applied $\left(\lambda_{j}>1\right)$. Based on this, it was deemed necessary to select six such latent factors for the generations $\mathrm{Y}$ and $\mathrm{X}$, and five for the $\mathrm{BB}$ generation. The level of indicators $\mathrm{KMO}$ in the analysis of the generations $\mathrm{Y}, \mathrm{X}$ and $\mathrm{BB}(0.823,0.849,0.852$, respectively) was acknowledged as acceptable because it should exceed 0.5 (Sztemberg-Lewandowska, 2008). Table 1 presents the characteristics obtained in the analyses of common factors $\left(F_{j}\right)$, eigenvalues $\left(\lambda_{j}\right)$, common variance $\left(\hat{h}_{j}\right)$, percentage of explained variance $\left(H_{k}\right.$ for $\left.j=1, \ldots, k\right)$, and the variables obtained in the individual main factors, the highest in respect of the module, factor loadings exceeding 0.5. 
Table 2. Characteristics of the factors

\begin{tabular}{|c|c|c|c|c|c|c|}
\hline \multicolumn{7}{|c|}{ Generation Y } \\
\hline$F_{j}$ & 1 & 2 & 3 & 4 & 5 & 6 \\
\hline$\lambda_{j}$ & 3.308 & 2.060 & 1.969 & 1.941 & 1.490 & 1.062 \\
\hline$\hat{h}_{j}$ & 17.412 & 10.840 & 10.365 & 10.216 & 7.840 & 5.589 \\
\hline$H_{k}$ & 17.412 & 28.252 & 38.617 & 48.833 & 56.673 & 62.262 \\
\hline $\begin{aligned} f_{j i} & >0.5 \\
\left(* f_{j i}\right. & >0.7)\end{aligned}$ & $\begin{array}{c}\mathrm{X} 2^{*}, \mathrm{X} 1^{*}, \mathrm{X} 6^{*}, \\
\mathrm{X} 7, \mathrm{X} 11\end{array}$ & $\mathrm{X} 5^{*}, \mathrm{X} 4^{*}, \mathrm{X} 8$ & $\mathrm{X} 15^{*}, \mathrm{X} 16^{*}$ & $\mathrm{X} 17^{*}, \mathrm{X} 18^{*}$ & $\mathrm{X} 13^{*}, \mathrm{X} 14^{*}$ & $\mathrm{X} 19^{*}, \mathrm{X} 9$ \\
\hline \multicolumn{7}{|c|}{ Generation X } \\
\hline$F_{j}$ & 1 & 2 & 3 & 4 & 5 & 6 \\
\hline$\lambda_{j}$ & 3.320 & 2.461 & 1.995 & 1.915 & 1.521 & 1.047 \\
\hline$\hat{h}_{j}$ & 17.475 & 12.952 & 10.501 & 10.081 & 8.005 & 5.508 \\
\hline$H_{k}$ & 17.475 & 30.426 & 40.927 & 51.008 & 59.013 & 64.522 \\
\hline $\begin{array}{c}f_{j i}>0.5 \\
\left(* f_{j i}>0.7\right)\end{array}$ & $\begin{array}{c}\mathrm{X} 2^{*}, \mathrm{X} 1^{*}, \mathrm{X} 6{ }^{*}, \\
\mathrm{X} 7, \mathrm{X} 3, \mathrm{X} 11\end{array}$ & $\mathrm{X} 4^{*}, \mathrm{X} 5^{*}, \mathrm{X} 8$ & $\mathrm{X} 15^{*}, \mathrm{X} 16^{*}$ & $\mathrm{X} 17^{*}, \mathrm{X} 18^{*}$ & $\mathrm{X} 13^{*}, \mathrm{X} 14^{*}$ & $\mathrm{X} 19^{*}, \mathrm{X} 9$ \\
\hline \multicolumn{7}{|c|}{ Generation BB } \\
\hline$F_{j}$ & 1 & 2 & 3 & 4 & 5 & \\
\hline$\lambda_{j}$ & 3.529 & 2.421 & 2.148 & 1.586 & 1.505 & \\
\hline$\hat{h}_{j}$ & 18.574 & 12.740 & 11.303 & 8.345 & 7.920 & \\
\hline$H_{k}$ & 18.574 & 31.315 & 42.618 & 50.963 & 58.883 & \\
\hline $\begin{array}{c}f_{j i}>0.5 \\
\left(* f_{j i}>0.7\right)\end{array}$ & $\begin{array}{c}\mathrm{X} 2^{*}, \mathrm{X} 1^{*}, \mathrm{X} 6{ }^{*}, \\
\mathrm{X} 7, \mathrm{X} 11, \mathrm{X} 3\end{array}$ & $\begin{array}{c}\mathrm{X} 5^{*}, \mathrm{X} 8, \mathrm{X} 4 \\
\mathrm{X} 10\end{array}$ & $\begin{array}{c}\mathrm{X} 15^{*}, \mathrm{X} 16^{*}, \\
\mathrm{X} 12\end{array}$ & $\begin{array}{l}\mathrm{X} 17^{*}, \mathrm{X} 18^{*}, \\
\mathrm{X} 19\end{array}$ & $\mathrm{X} 13^{*}, \mathrm{X} 14^{*}$ & \\
\hline
\end{tabular}

Source: own calculations using the program PS IMAGO PRO 5.1.

Based on the conducted analysis, one should note the similarities in the construction of the latent variables for generations $\mathrm{Y}$ and $\mathrm{X}$ - the difference occurs only in the case of factors constituting the first latent variable. For the analysis carried out for generation $\mathrm{BB}$, the number of the latent variables is smaller and is made up from a different set of factors than in the case of the younger generations. Table 2 presents the variables used to distinguish the main factors in order of their strongest influence.

For generation $\mathrm{Y}$ one can name the following main factors describing the subjective feelings of the respondents:

F1 - my country: the most important factors were the opinions about the economy and general condition of the country, and its job market; the creation of this factor was also greatly influenced by the evaluation of public services and the country's democracy; 
F2 - my home: the most significant factors influencing the distinction of this variable were the financial condition of the household and satisfaction from one's personal situation in working life, followed by another important factor of the general assessment of satisfaction with one's life;

F3 - I am a European: this variable was created from the reduction of the level of assessment regarding being a part of the EU;

F4 - I am recognized: this variable is created from feelings about the statements my voice counts in my country and in the EU;

F5 - I am attached to my country: this variable was created from reducing the level of assessment regarding being attached to one's place of residence and the country;

F6 - I voice my opinions: the most relevant factor creating this variable was the ability to convince others to accept one's opinion, while the weaker influence on this construction came from the expectations about one's life.

The variables which did not take part in creating latent variables were some of the opinions linked with the EU, such as its economy, quality of life before and after accession, as well as satisfaction with EU democracy.

In the case of generation $X$, the set of latent variables remained very close to the distinguished latent variables for generation Y. The only difference occurs in the first variable F1 (my country), where the factors already mentioned are extended by the assessment of the EU economy.

For generation $\mathrm{BB}$, the determined structure consisted of five latent variables:

F1 - my country: the most important factors were the opinions about the economy and the general condition of the country and its jobs market; the assessment of public services and satisfaction with the country's democracy were also significant in creating that factor, while the assessment of the EU economy played a much smaller part;

F2 - my home: the most important factor in distinguishing this variable was the financial condition of the household, followed by the general level of satisfaction with life, with one's position at work and comparison of the quality of life before and after accession;

F3 - I am European: this variable was created from reducing the level of assessment regarding being a part of the EU and Europe, and to a lesser degree the assessment of being satisfied with EU democracy; 
F4 - I am recognized: this variable was created from the perceptions regarding the statements that my voice counts in the country and in the EU and to a lesser degree with the ability to convince others to accept one's own opinion;

F5 - I am attached to my country: this variable was created from reducing the level of assessment regarding being attached to one's place of residence and country.

The only factor which did not take part in distinguishing the latent variables were the expectations about one's life which constituted a significant factor for generations $\mathrm{Y}$ and $\mathrm{X}$.

\section{The search for the models of projecting the evaluation of the household on the assessment of an individual's further environment}

The Correspondence analysis was used to verify the second research hypothesis. In view of the occurrence in the research of numerous variables it was necessary to apply the solutions enabling their joint analysis, at the same time aiming to retain the highest possible quality of the connections between the categories despite the reduced multivariance. Since the correspondence analysis is a method which allows presenting the real connections between the categories of variables in a low-dimensional space, it is necessary to evaluate the degree in which the real connections are replicated in the space with a significantly lower variance. Table 3 presents the results of the analyses in respect of the three generations of Europeans divided into groups, where: the variance of the real space of the connections $-K$, variance of the space of projection (presentation) of connections $K^{*}$, the degree of explained inertia in $K^{*}$-dimensional space, and the degree of explained inertia on the basis of the scree test. The results are shown in four variants of the correspondence analysis.

Table 3. Evaluations of the proposed solutions using four variants of the correspondence analysis as the percentage of explained inertia $\left(\tau_{K^{*}}\right)$

\begin{tabular}{|c|c|c|c|c|c|}
\hline \multirow{2}{*}{$\begin{array}{c}\text { Type } \\
\text { of analysis }\end{array}$} & $K$ & \multicolumn{2}{|c|}{$\begin{array}{c}K^{*} \text { and } \\
\tau_{K^{*}} \text { in scree test }\end{array}$} & \multicolumn{2}{|c|}{$\tau_{K^{*}}$} \\
\hline 1 & 2 & 3 & $K^{*}=2$ & $K^{*}=3$ & $K^{*}=5$ \\
\hline \multicolumn{7}{|c|}{ Generation Y } & 16.33 & 22.52 \\
\hline 1 & 73 & $9(31.99)$ & 12.46 & 21.46 & 31.25 \\
\hline 2 & 25 & $5(31.25)$ & 27.81 & 34.83 & 45.48 \\
\hline 3 & 31 & $5(45.48)$ & $\mathbf{3 2 . 3 2}$ & $\mathbf{3 9 . 1 6}$ & $\mathbf{5 0 . 1 7}$ \\
\hline $\mathbf{4}$ & $\mathbf{3 1}$ & $\mathbf{5 ( 5 0 . 1 7 )}$ & &
\end{tabular}




\begin{tabular}{|c|c|c|c|c|c|}
\hline 1 & 2 & 3 & 4 & 5 & 6 \\
\hline \multicolumn{7}{|c|}{ Generation X } \\
\hline 1 & 73 & $9(32.68)$ & 13.42 & 17.08 & 23.35 \\
\hline 2 & 25 & $7(42.4)$ & 17.58 & 23.82 & 33.73 \\
\hline 3 & 31 & $5(51.21)$ & 32.78 & 40.92 & 51.21 \\
\hline $\mathbf{4}$ & $\mathbf{3 1}$ & $\mathbf{6 ( 6 7 . 0 1 )}$ & $\mathbf{4 1 . 0 9}$ & $\mathbf{5 2 . 6}$ & $\mathbf{6 3 . 6 7}$ \\
\hline \multicolumn{7}{|c|}{ Generation BB } \\
\hline 1 & 73 & $9(32.43)$ & 13.36 & 17.07 & 23.23 \\
\hline 2 & 25 & $4(28.3)$ & 17.37 & 23.24 & 32.85 \\
\hline 3 & 31 & $4(45.34)$ & 32.59 & 40.12 & 49.73 \\
\hline $\mathbf{4}$ & $\mathbf{3 1}$ & $\mathbf{5 ( 6 0 . 1 6 )}$ & $\mathbf{3 9 . 5 6}$ & $\mathbf{4 9 . 3 9}$ & $\mathbf{6 0 . 1 6}$ \\
\hline
\end{tabular}

Source: own elaboration using the Statistica program.

The solutions based on the simultaneous inclusion of all the variables and using the Burt matrix should be ranked lowest. The presentation conducted in the two, three and five-dimensional or even in nine-dimensional spaces leads to the lowest degree of retaining information about the connections between the categories of variables.

In conducting the other variants of analysis the decision was made to check, through the prism of assessing the functioning of households, what are the evaluations of the other two areas of individuals' functioning, i.e. the locality/country and the EU/Europe.

The second variant was based on constructing the Burt matrix between two variables describing a household, while the categories of variables describing the locality/country and the EU/Europe were introduced to the analysis as supplementary points. Such a procedure was widely discussed by J. Blasius (2001), M. Greenacre (1984), and A. Stanimir (2005). In this variant, the analyses carried out for all the generations showed a significant reduction of variance of the full-dimensional space, at the same time obtaining for all the selected variances of the projection space of connections the results which were better in relation to retaining the connections between the categories.

For the third solution, again the Burt matrix was determined on the basis of the variables characterizing households. Then the process of reconstituting that matrix was carried out in order that in the matrix in the diagonal tables outside the diagonal, no zeroes appeared. This procedure was described by J.-P. Benzecrie (1992), M. Greenacre (1984), P.G.M. Heijden (1987), and H.O. Lancaster (1958). The such created new matrix was the subject of the correspondence analysis in its classic form, and the categories of variables describing the locality/country and the EU/Europe were introduced to the analysis results as supplementary points. Due to this 
procedure we obtained the improved quality of the presented connections between the categories of variables in the spaces with a low (compared to the real) variance.

However, the best results were obtained following the use of a concatenated Burt matrix, combining the Burt matrix of the variables describing households with the contingency tables of the variables describing the locality/country and the EU/Europe.

It should be noted that, independently of the selected variant of using the correspondence analysis, the mutual positioning of points in two and three-dimensional spaces, i.e. those replicating to the highest degree the real connections between the categories of variables, does not change.

Due to the highest quality of replicating the real connections between categories, in the subsequent analysis we used the results obtained on the basis of the fourth variant. The Scree test indicated the presentation of the results of the analysis carried out in five-dimensional space, and therefore the search for concurrent categories was carried out using the hierarchical classification based on the coordinates of projecting the categories of the analysed variables. The choice of the bind which has to be cut in the obtained diagrams was made on the basis of the Silhouette index, which for the generations Y, X, and BB was, respectively from: 0.603 (eight classes), 0.557 (five classes), and 0.582 (nine classes). Figures 1 to 3 show the median values of the coordinates (W) in the individual classes containing categories of the variables determined for generations $\mathrm{Y}$ (Figure 1), X (Figure 2), and BB (Figure 3).

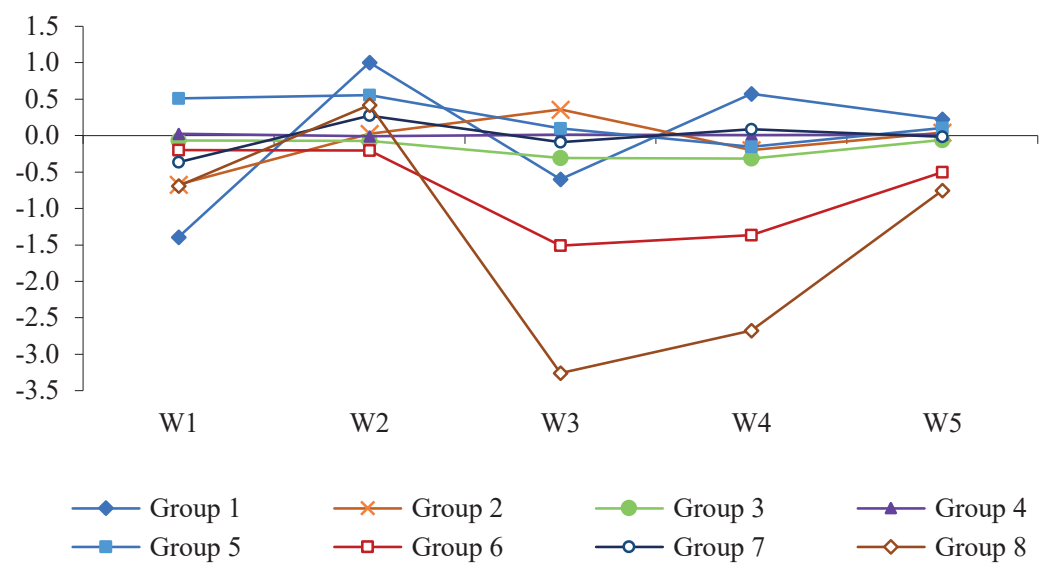

Figure 1. Results of variable categories classification for Generation Y

Source: own elaboration using the Statistica program on Eurobarometer data. 


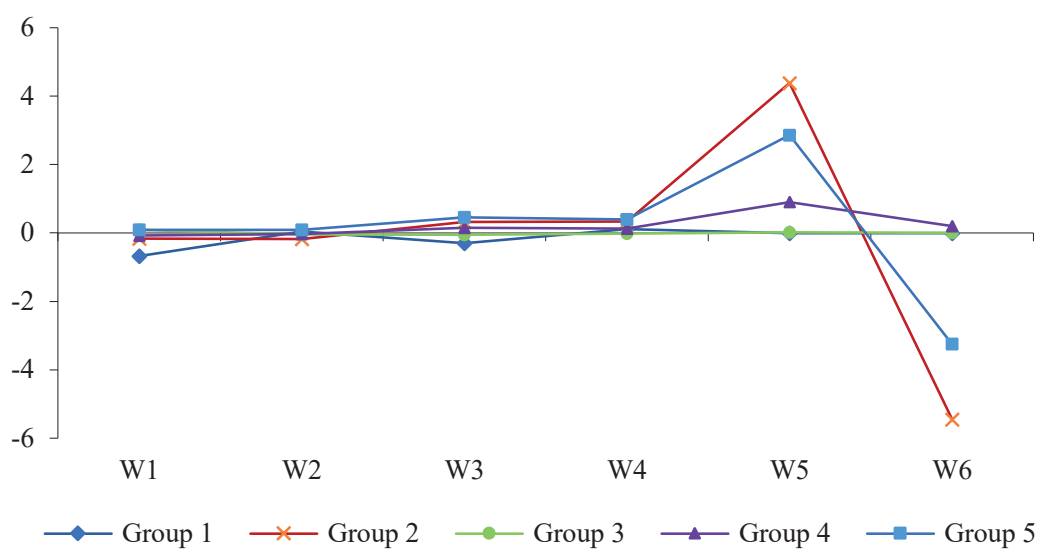

Figure 2. Results of variable categories classification for Generation X

Source: own elaboration using the Statistica program on Eurobarometer data.

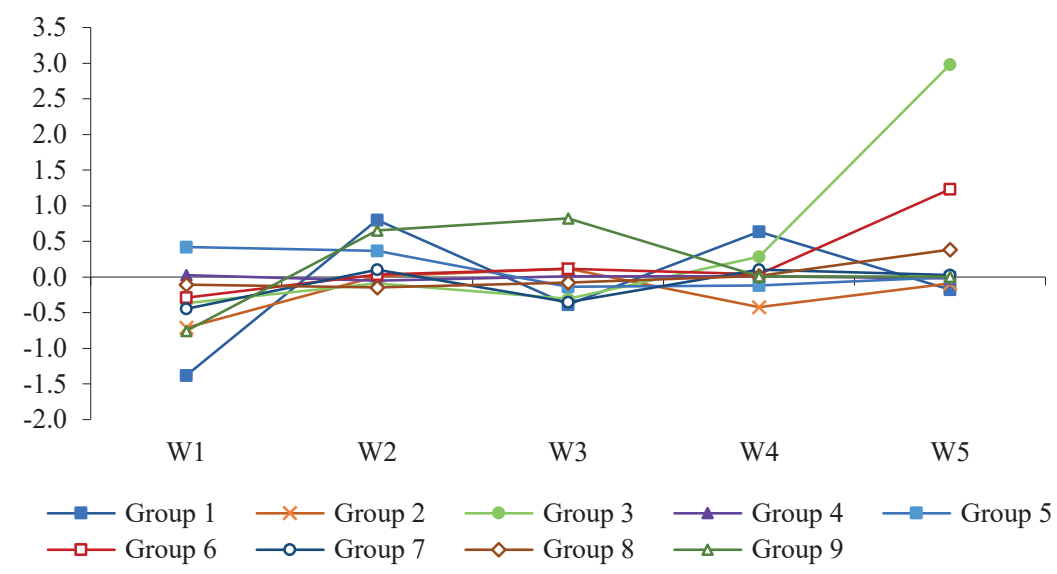

Figure 3. Results of variable categories classification for Generation BB

Source: own elaboration using the Statistica program on Eurobarometer data.

The presented median values of the coordinates $\left(\mathrm{W}_{\mathrm{i}}\right)$ in the distinguished groups (Figures 1 to 3) help with evaluating the similarities of the groups and the distance or closeness of their location in respect of the centre of gravity in the five-dimensional space of solutions in the correspondence analysis for generations $\mathrm{Y}$ and BB, and the six-dimensional one for generation X. 
For generation $\mathrm{Y}$ the following groups of Europeans were distinguished:

a) group 1: very bad evaluation of the household's condition in terms of its professional and financial standing and the quality of life; these persons differ significantly in their opinions from the evaluations of the others;

b) group 2: bad evaluation of the household's condition in terms of its professional and financial standing and the quality of life, and the view that life will not change in future;

c) group 3: persons who never convince others to their own opinions and are unable to evaluate the condition of the country, their own identity and value; the group is located close to the centre of projection (Figure 1);

d) group 4: points reflecting good and bad evaluations of the prevalent majority of the questions, also the persons who have a very good opinion of the EU and feel attached to their own country as well as being European, know that their voices are noted both at home and abroad; the group is located closely to the centre of the projection (Figure 1);

e) group 5: very good evaluation of the condition of the household and the view that the quality of life has significantly improved following accession; this class differs notably in their opinions from the others;

f) group 6: inability to define the values in X5, X8, and X14 (located closely to group 8 - Figure 1);

g) group 7: very bad opinions in many aspects of both the country and the EU;

h) group 8: inability of defining the values in X13 (located closely to group 6 - Figure 1).

For generation $\mathrm{X}$ the following groups of Europeans were distinguished:

a) group 1: persons highly dissatisfied with the condition of their household, country and the EU; points characterizing persons from that group are located closely to the centre of gravity (Figure 2), thus it is impossible to state that this class impacts strongly on the evaluations made by Europeans;

b) group 2: persons who are satisfied with their lives and are attached to their place of residence; in the case of that group it can be noted (Figure 2), that its distinguishing was strongly affected by conducting the analysis in a six-dimensional space, and not, e.g. in the two-dimensional one; through the addition of axes five and six, the differences were discovered between this group and the others;

c) group 3: includes persons satisfied and very satisfied with their own household, and at the same time satisfied and very satisfied with the situation in their country and in 
the EU, yet its closest location to the projection centre, just as for group 1, indicates the small importance of the category of these variables for distinguishing the groups;

d) group 4: persons who are unable to evaluate as good or bad the situation of their household, as well as that of the country and the EU, however it should be pointed out that just as in the case of distinguishing group 2, the introduction of the fifth and the sixth main axes into the solution allowed for determining that group;

e) group 5: persons who significantly differ from the others, and their main characteristic is the lack of either a positive or negative view of their attachment to their country, hence it is hard to expect that they would be able to evaluate clearly the condition of their country and the EU through the prism of the evaluation of their own household.

For generation BB the following groups of Europeans were distinguished:

a) group 1: very bad evaluation of the condition of the household in terms of its professional and financial standing and the quality of life; these persons' evaluations differ greatly from the others, while the categories describing this group are distinguished from other groups by their location in a five-dimensional space (Figure 3);

b) group 2: bad evaluation of the condition of the household in terms of its professional and financial standing and the quality of life, as well as very low expectations regarding life in general;

c) group 3: persons who are unable to assess whether they are satisfied with their life and their attachment to the place of residence;

d) group 4: points reflecting good and bad evaluations for the significant majority of the questions referring to the household, and the same evaluations regarding the country of residence and the EU; the group located close to the projection centre - Figure 3;

e) group 5: very good evaluation of the condition of the household (professional and financial standing, satisfaction with one's life) and the view that the quality of life after accession has improved significantly; high evaluation of the household corresponds with the very high assessment of the country, both domestic and EU economy, domestic job market and public services, democracy in the country and in the EU; this class differs significantly from the others in a two-dimensional space;

f) group 6: persons who evaluate neither as good nor bad the financial condition of the household, and are unable to state whether they feel attached to their country or not, while they decidedly think that that their voice counts in the country; 
g) group 7: persons who evaluate in a very negative way all the analysed variables in areas such as the place/country of residence and the EU/Europe, and these features are also linked with a very low evaluation of their attachment to the place of residence;

h) group 8: persons who evaluate neither as good nor bad their satisfaction with life, and are also unable to decide about the evaluation of the variables related to the place/ country of residence and the EU/Europe (located closely in respect of the centre of gravity and group 4 - Figure 3);

i) group 9: persons claiming categorically that life was better before accession.

\section{Conclusions}

The use of the correspondence analysis made it possible to recognize for the generation $\mathrm{X}$ that the assessments of socio-economic characteristics describing the close, near and distant area of the entity's functioning are interweaving. Thus, the results obtained confirmed the hypotheses $\mathrm{H} 1$ and $\mathrm{H} 3$. Based on the results of the method used, it was pointed out that positive assessments made by respondents for features describing the socio-economic situation of households are associated with the positive evaluation of variables describing the situation of the country and Europe and the European Union. Similarly, for the negative ratings. For generation Y and generation $\mathrm{BB}$, the correspondence analysis has identified individuals who rated the situation in households very well and those who rated it very poorly. However, no significant coexistence with negative and positive assessments of the situation in the country and the European Union was indicated. It should be indicated, that only respondents belonging to generations BB and X, who assessed the situation of the household very well stated that the quality of life significantly improved after accession.

Therefore, it should be noted that the correspondence analysis in the proposed variant of the construction of the data table is very useful, due to the possibility of presenting many variables described in many categories, but with a very high quality display of relations between the categories of variables.

The factor analysis allowed indicating for each generation similar components of five latent variables. Due to the purpose of the analysis, it is important that latent factors such as my country, my home, I am a European are distinguished. The structure of the first latent variable was affected by the most number of observed variables. For each generation, the most important factors were in this case the opinion about the economy and general condition of the country and its labour market. For the latent variable my home the most important factors for its construction, 
in the case of generation $\mathrm{Y}$ and $\mathrm{X}$, were the financial condition of the household and satisfaction with the personal situation at work. In the creation of this latent variable for the BB generation four variables took part: the financial condition of the household, life satisfaction, personal situation at work and quality of life after accession. Satisfaction with EU democracy was the most important factor for the latent variable I am European, but only for the BB generation. For the other two groups of respondents, this factor was irrelevant in creating the latent variable.

The conclusions of the study also orient future research. An analogous method of analysis needs to be used in the deeper division of EU society. The analysis with the same set of variables and three generations should be carried out in individual member countries or dividing these countries into groups depending on the moment of accession. It is also important to check whether the perceptions of these factors differ over time. Another element requiring further research is checking whether the division of respondents into three generations and considering the perception of factors related to the assessment of the quality of life is possible with the preconceived division of these factors into three groups related to the respondents' environment: household, country, Europe. To this end, it is possible to use structural equations and compare the results with those obtained in the presented analysis. The authors will undertake solutions to the above problems in the future.

\section{References}

Backhaus, K., Erichson, B., Plinke, W., Weiber, R. (2003). Multivariate Analysemethoden. Berlin: Springer.

Bąkowska, J. (2013). Managing Generation Y employees in an international company. Management, Finance and Economics, 1 (14).

Belleau, B.D., Summers, T.A., Xu, Y., Pinel, R. (2007). Theory of Reasoned Action Purchase Intention of Young Consumers. Clothing \& Textiles Research Journal, 25 (3), 244-257. DOI: $10.1177 / 0887302 X 07302768$.

Benzécrie, J.-P. (1992). Correspondence Analysis Handbook. New York: Marcel Dekker Inc.

Blasius, J. (2001). Korrespondenzanalyse. München: Oldenbourg Verlag.

European Commission. (2019). Eurobarometer 90.3(2018). Kantar Public [producer]. GESIS Data Archive, Cologne. ZA7489 Data file Version 1.0.0. DOI: 10.4232/1.13254. 
Favero, W.L., Heath., G.R. (2012). Generational Perspectives in the Workplace: Interpreting the Discourses That Constitute Women's Struggle to Balance Work and Life. Journal of Business Communication, 49 (4), 332-356. DOI: 10.1177/0021943612456037.

Greenacre, M. (2010). Biplots in practice. Bilbao: Fundacion BBVA.

Greenacre, M., Blasius, J. (eds.) (2006). Multiple Correspondence Analysis and Related Methods. Boca Raton, Chapman \& Hall/CRC. Taylor \& Francis Group.

Hansen, J.-I.C., Leuty, M.E. (2012). Work Values Across Generations. Journal of Career Assessment, 20 (1), 34-52. DOI: 10.1177/1069072711417163.

Haque, M.M., Maheshwari, N. (2015). Consumer Ethnocentrism and Influence of Role Model on Generational Cohorts' Purchase Intentions towards Herbal Products. Asia-Pacific Journal of Management, Research and Innovation, 11 (4), 305-312. DOI: $10.1177 / 2319510 X 15609989$.

Heijden van der, P.G.M. (1987). Correspondence Analysis of Logitudinal Categorical Data. Leiden: DSWO Press.

Jakość życia w Polsce (2017). Warszawa: Główny Urząd Statystyczny.

Kim, J.-O., Mueller, C. (1978). Factor Analysis. Statistical Methods and Practical Issues. Beverly Hills: Sage Publication Inc.

Lancaster, H.O. (1958). The structure of Bivariate Distributions. The Annals of Mathematical Statistics, 29 (3), 719-736.

Lebart, L. Morineau, A., Warwick, K.M. (1984). Multivariate Descriptive Statistical Analysis. Correspondence Analysis and Related Techniques for Large Matrices. New York: John Wiley \& Sons, Inc.

Lichy, J. (2012). Towards an international culture: Gen Y students and SNS? Active Learning in Higher Education, 13 (2), 101-116. DOI: 10.1177/1469787412441289.

Lyons, S.T., Duxbuky, L., Higgins, C. (2007). An empirical assessment of generational differences in basic human values. Psychological reports, 101, 339-352.

Madudova, E., Fabuš, J. (2017). A study of consumer behaviour of active usage of instant messaging applications. International Journal of Economics, Business and Management Research, 1 (5), 350-357.

Mencl, J., Lester, S.W. (2014). More Alike Than Different: What Generations Value and How the Values Affect Employee Workplace Perceptions. Journal of Leadership \& Organizational Studies, 21 (3), 257-272. DOI: 10.1177/1548051814529825.

Olsson, M., Schuller, B.J. (2012). Living standard, quality of life, globalization and competitiveness in the EU and the neighbour countries - an empirical analysis. Acta Sci.Pol. Oeconomia, 11 (1), 5-21.

Nowak, P. (2018). Zróżnicowanie jakości życia mieszkańców gmin wiejskich województwa świętokrzyskiego. Wiadomości Statystyczne, 4 (683), 73-88. 
Ngobo, P.V., Devallet-Ezanno, D. (2010). Do Generations Matter in Customer Defection? Recherche et Applications en Marketing, 25 (3), 86-112.

Parry, E., Urwin, P. (2011). Generational Differences in Work Values: A Review of Theory and Evidence. International Journal of Management Reviews, 13, 79-96. DOI: 10.1111/j.14682370.2010.00285.x.

Ptak-Chmielewska, A. (2009). Metoda głównych składowych i analiza czynnikowa. In: E. Frątczak (ed.), Wielowymiarowa analiza statystyczna. Teoria - przykłady zastosowań z systemem SAS. Warszawa: Szkoła Główna Handlowa w Warszawie.

Sagan, A. (1998). Badania marketingowe. Podstawowe kierunki. Kraków: Wydawnictwo Akademii Ekonomicznej w Krakowie.

Soulez, S., Guillot-Soulez, C. (2011). Recruitment marketing and generational segmentation: a critical analysis based on a sub-segment of Generation Y. Recherche et Applications en Marketing, 26 (1).

Stanimir, A. (2005). Analiza korespondencji jako narzędzie do badania zjawisk ekonomicznych. Wrocław: Wydawnictwo AE we Wrocławiu.

Sztemberg-Lewandowska, M. (2008). Analiza czynnikowa w badaniach marketingowych. Wrocław: Wydawnictwo Uniwersytetu Ekonomicznego we Wrocławiu.

Treuren, G., Anderson, K. (2010). The employment expectations of different age cohorts: is generation Y really that different? Australian Journal of Career Development, 19 (2).

Twenge, J.M., Campbell, S.M., Hoffman, B.J., Lance, C.E. (2010). Generational Differences in Work Values: Leisure and Extrinsic Values Increasing, Social and Intrinsic Values Decreasing. Journal of Management, 36 (5), 1117-1142. DOI: 10.1177/0149206309352246.

Twenge, J.M., King, L.A. (2005). A good life is a personal life: Relationship fulfillment and work fulfillment in judgments of life quality. Journal of Research in Personality, 39, 336353. DOI: 10.1016/j.jrp.2004.01.004.

Vui-Yee1, K., Khoo, P. (2018). The Effect of Work Fulfilment on Job Characteristics and Employee Retention: Gen Y Employees. Global Business Review, 21 (2), 1-15. DOI: 10.1177/0972150918778912. 